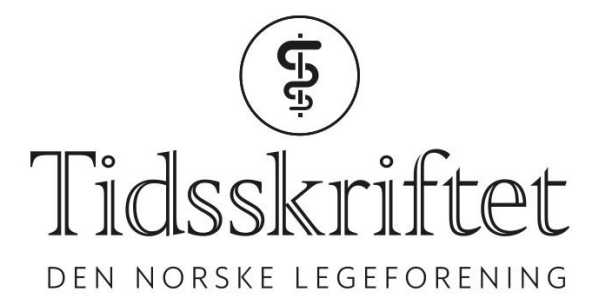

\title{
HPV-vaksinene gir god beskyttelse
}

KOMMENTAR

\section{DIDRIK F. VESTRHEIM}

E-post: didrik.frimann.vestrheim@fhi.no

Didrik F. Vestrheim er avdelingsdirektør ved Avdeling for vaksineforebyggbare sykdommer, Folkehelseinstituttet.

Ingen oppgitte interessekonflikter.

\section{BRITT WOLDEN}

Britt Wolden er avdelingsdirektør ved Avdeling for vaksine, Folkehelseinstituttet. Ingen oppgitte interessekonflikter.

Folkehelseinstituttet har nylig gjennomført anbudskonkurranse for HPV-vaksine til jenter i 7. klasse. To HPV-vaksiner deltok, en nivalent vaksine (Gardasil 9 (MSD)) og en bivalent vaksine (Cervarix (GSK)). Den bivalente vaksinen ble valgt. Professor emeritus Harald Moi hevder i Tidsskriftet nr. 10/2017 at beslutningen vil gi norske kvinner et dårligere helsetilbud (1). Selv om dagens dokumentasjon viser tilnærmet like god beskyttelse for de to vaksinene $(2,3)$, mener Moi at den direkte beskyttelsen av den nivalente vaksinen vil vare lenger enn kryssbeskyttelsen av Cervarix. Moi skriver at den nivalente vaksinen vil kunne gi en større innsparing for dagens livmorhalsscreeningprogram, og at det er betenkelig å se bort fra beskyttelse mot kjønnsvorter i valg av HPV-vaksine til vaksinasjonsprogrammet.

Folkehelseinstituttet er uenig i Mois vurdering. Vi beskriver her hvordan vaksiner til vaksinasjonsprogrammet anskaffes, og begrunner vurderingen og valget av vaksine.

Alle vaksiner til barnevaksinasjonsprogrammet kjøpes inn etter regler for offentlige anskaffelser. Dokumentert effekt slik den gjenspeiles i vaksinens produktinformasjon (SPC) legges til grunn for vurderingen. I den nylig gjennomførte anbudskonkurransen ble begge vaksinene vurdert som svært gode. Begge vaksinene inneholder antigener fra de onkogene HPV-typene 16 og 18 som forårsaker minst 70\% av all livmorhalskreft og opptil $94 \%$ av andre HPV-relaterte kreftformer hos kvinner og menn. Den nivalente vaksinen inneholder ytterligere fem onkogene HPV-typer og to HPV-typer som er årsak til kjønnsvorter (HPV 6 og 11). Tross forskjellig antigeninnhold er dokumentert effekt mot forstadier til livmorhalskreft likeverdig: For det første, hos kvinner som ikke har vært utsatt for HPVsmitte kan den bivalente vaksinen dokumentere over 90\% beskyttelse uavhengig av HPVtype (2). For det andre, den nivalente vaksinen kan vise nær 100\% beskyttelse mot de HPVtypene som vaksinen inneholder, som forårsaker rundt 90\% av livmorhalskrefttilfellene (3). Ut fra dagens dokumentasjon gir dermed vaksinene likeverdig beskyttelse mot forstadier til livmorhalskreft (4).

Dokumentasjon som kan komme i fremtiden kan ikke vektlegges i anbudskonkurransen. Det gjelder spørsmål knyttet til langtidseffekt av begge vaksinene. Siden vaksinene vurderes 
å gi likeverdig beskyttelse, vil begge kunne gi forenklinger i livmorhalsprogrammet i fremtiden, når redusert forekomst av alvorlige celleforandringer og livmorhalskreft hos vaksinerte er dokumentert. Det vil imidlertid ta flere år.

Den bivalente vaksinen har vært lenger i markedet og har lengst oppfølgingstid både for effekt og sikkerhet (bivirkninger). Denne vaksinen kom derfor best ut i totalvurderingen for kvalitet, der både effekt og sikkerhet inngår.

Folkehelseinstituttet deler Mois syn på at kjønnsvorter kan utgjøre en stor belastning for dem som rammes. For vaksiner i barnevaksinasjonsprogrammet er imidlertid en av forutsetningene at sykdommen som skal forebygges er alvorlig. HPV-vaksine er innført i barnevaksinasjonsprogrammet for å forebygge kreft. Beskyttelse mot kjønnsvorter blir vurdert i anbud, men er ikke avgjørende for valg av vaksine.

\section{LITTERATUR:}

1. Moi H. Dårligere vaksine mot humant papillomvirus. Tidsskr Nor Legeforen 2017; 137: 700. [PubMed][CrossRef]

2. Cervarix SPC. (GSK).

http://www.ema.europa.eu/docs/no_NO/document_library/EPAR_-_Product_Info has been redirected to http://www.ema.europa.eu/docs/en_GB/document_library/contacts/not_yet_av... (9.6.2017).

3. Gardasil SPC. 9 (MSD).

http://www.ema.europa.eu/docs/no_NO/document_library/EPAR_-_Product_Info has been redirected to http://www.ema.europa.eu/docs/en_GB/document_library/contacts/not_yet_av... (9.6.2017).

4. Human papillomavirus vaccines: WHO position paper May, 2017.

http://apps.who.int/iris/bitstream/10665/255353/1/WER9219.pdf?ua=1 (9.6.2017).

Publisert: 21. august 2017. Tidsskr Nor Legeforen. DOI: 10.4045/tidsskr.17.0585

(C) Tidsskrift for Den norske legeforening 2020. Lastet ned fra tidsskriftet.no 